\title{
TAXONOMIC AND DISTRIBUTIONAL ASSESSMENTS OF Chaerephon plicatus (Chiroptera: Molossidae) FROM VIETNAM
}

\author{
Vu Dinh Thong \\ Institute of Ecology and Biological Resources, VAST, vietnambat@ gmail.com
}

\begin{abstract}
To date, Wrinkle-lipped Bat (Chaerephon plicatus) is the only species of the family Molossidae in Vietnam. It is found throughout much of Asia but rarely recorded in the country. Every published record of this species from Vietnam was only resulted from a single individual with little data on morphology. Particularly, the previous publications did not include any information about either colony size or roosting site of the species within Vietnam. Between 2001 and 2014, a series of field surveys was conducted throughout the country with an intensive search for free-tailed bat species. The obtained results indicate that Wrinkle-lipped Bat is a widespread bat species but its known roosting sites in Vietnam are quite distjunct. Its colony size is in both seasonal and geographical variations ranging from several hundreds to over three million individuals. The species inhabits seasonally and permanently in northern and southern regions, respectively. This paper provides taxonomic and ecological assessments with an emphasis on morphological measurements, colony size, roosting habitats and national distributional range of Wrinkle-lipped Bat within Vietnam.
\end{abstract}

Keywords: Asia, behavior, free-tailed bat, habitat, Mammalia, seasonal variation.

\section{INTRODUCTION}

Wrinkle-lipped Bat (Chaerephon plicatus) is a free-tailed species, which was originally described as Vespertilio plicatus (Buchannan 1800). Subsequently, the species was reclassified as Tadarida (Chaerephon) plicata $[1,6]$, Chaerephon plicata $[2,12]$ and Chaerephon plicatus [5, 9]. Freeman (1981) [10] delineated that Tadarida and Chaerephon are two distinct genera. This paper identifies the materials from Vietnam as Chaerephon plicatus following Simmons (2005) [15] and Francis (2008) [9].

Simmons (2005) [15] included a total of 111 free-tailed bat species belonging to 17 genera worldwide: Chaerephon, Cheiromeles, Cynomops, Eumops, Mormopterus, Molossops, Molossus, Mops, Myopterus, Neoplatymops, Nyctinomops, Otomops, Platymops, Promops and Tomopeas. Of which, 19 species belong to the genus Chaerephon. Within the Southeast Asian region, free-tailed bats currently comprise 6 species belonging to 5 genera: Chaerephon plicatus, C. johorensis, Cheiromeles torquatus, Mops mops, Otomops wroughtoni and Tadarida latouchei [9]. The first published information of molossid bats from Vietnam was included in Total (1974) [17] with record of one specimen identified as Tadarida plicata. Since then, records of Tadarida plicata from the country has been included in a series of publications (Cao Van Sung 1976, Sokolov 1986, Corbet and Hill 1992, Dang Huy Huynh et al. 1994, Hendrichsen 2001, Borissenko and Kruskop 2003, Kruskop 2013). Borissenko and Kruskop (2003) [2] and Kruskop (2013) [12] assumed that "at least two other species could be found in Vietnam" and provided a key to Chaerephon plicata and three other species: Otomops wroughtoni, Tadarida latouchei and Tadarida insignis. According to results from the present study and several previous publications, distribution of Chaerephon plicatus in Vietnam is confirmed, whereas three later species (Otomops wroughtoni, Tadarida latouchei and Tadarida insignis) are still unrecorded from the country. On the other hand, almost nothing is known about roosting sites and colony sizes of free-tailed bats in Vietnam. This paper provides a taxonomic assessment, distributional and ecological data of Chaerephon plicatus from Vietnam.

MATERIALS AND METHODS 


\section{Bat capture}

Bats were captured and handled in the field following guidelines approved by the American Society of Mammalogists [14]. A total of nineteen specimens were collected from their roosting sites and examined for taxonomic confirmation. Of which, three specimens (IEBR-T.280808.3, IEBR-T.280808.4, IEBRT.280808.5, adult females, bodies in alcohol, skulls extracted) were collected from Lang Son province, northern Vietnam and sixteen remainders (IEBR-T.051214.6, adult female, body in alcohol, skull extracted; IEBRT.051214.4, IEBR-T.051214.5, IEBRT.051214.7, IEBR-T.051214.8, IEBRT.051214.9, IEBR-T.051214.10, IEBRT.051214.11, IEBR-T.051214.12, IEBRT.051214.13, IEBR-T.051214.14, IEBRT.051214.15, IEBR-T.051214.16, IEBRT.051214.17, IEBR-T.051214.18, IEBRT.051214.19, unsexed, adult, skulls only) were collected from Dong Nai province, southern Vietnam.

\section{Taxonomic and ecological assessments}

External and craniodental measurements were taken following Vu Dinh Thong (2011) [18], Vu Dinh Thong et al. (2012a, 2012b, 2012c) [19, 20, 21], Bates \& Harrison (1997) [1] and Csorba et al. (2003) [7]. The measurements comprise FA, forearm lengthfrom the extremity of the elbow to the extremity of the carpus with the wings folded; $\mathrm{EH}$, ear height-length of ear conch; TIB, tibia lengthfrom the knee joint to the ankle; HF, hind-foot length-from the extremity of the heel behind the os calcis to the extremity of the longest digit, excluding the hairs or claws; Tail: tail length, from the tip of the tail to its base adjacent to the body; SL, total length of skull-from occiput to the most anterior part of the canine; CCL, condylocanine length-from the exoccipital condyle to the most anterior part of the canine; IOW, interorbital width-the least width of the interorbital constriction; ZW, zygomatic widththe greatest width of the skull across the zygomatic arches; BW, width of braincase greatest width of the braincase at the posterior roosts of the zygomatic arches; C1-C1, upper canine width-greatest width, taken across the outer borders of upper canines; M3-M3, upper molar width-greatest width, taken across the outer crowns of the last upper molars; C1-M3, maxillary toothrow length-from the front of upper canine to the back of the crown of the third molar; $\mathrm{ml}$, mandible length-from the anterior rim of the alveolus of the first lower incisor to the most posterior part of the condyle; c1-m3, mandibular toothrow length-from the front of the lower canine to the back of the crown of the third lower molar. Reproductive status and age were assessed following Racey (2009) [13] and Brunet-Rossinni \& Wilkinson (2009) [3], respectively. IEBR-T. is an acronym for the bat collection of $\mathrm{Vu}$ Dinh Thong, retained at the Institute of Ecology and Biological Resources (IEBR), Hanoi, Vietnam. Distributional ranges were assessed following data from field surveys and published information. Estimation of the numbers of individuals inhabiting each locality was based on results from observational counting at the front of caves when bats were emerging at dusk. Video cameras were utilised to shoot clips for replaying to reevaluate the observed colony sizes.

\section{RESULTS AND DISCUSSION}

\section{Taxonomy}

Table 1. External measurements (in $\mathrm{mm}$ ) of Chaerephon plicatus from Vietnam

\begin{tabular}{lcccc}
\hline Parameter & mean & SD & range & $\mathrm{n}$ \\
\hline FA & 48.24 & 1.37 & $46.24-49.32$ & 4 \\
EH & 18.63 & 1.30 & $17.57-20.08$ & 3 \\
TIB & 16.34 & 0.15 & $16.20-16.53$ & 4 \\
HF & 9.66 & 1.35 & $8.11-11.40$ & 4 \\
Tail & 37.41 & 1.88 & $35.15-39.37$ & 4 \\
\hline
\end{tabular}

External and craniodental characteristics of all specimens obtained during the present study exhibit well the diagnoses of Chaerephon plicatus. Their forearm length ranges from 46.24 to $49.32 \mathrm{~mm}$ with an average of 48.24 $\mathrm{mm}(\mathrm{n}=4$; table 1$)$. The ears are fleshy and connected by a membrance across the forehead (fig. 1). Each ear has a blunt tip. Its anterior and 
posterior borders are slightly convex and waved, respectively. There are six fleshy transverse ridges on the posterior lobe (fig. 1). The eyes are large (in comparison with those of other microchiropteran bat species). The upper lip is well developed and wrinkled. Nottrils open sidewards. The pelage is soft, dense and mostly uniform chestnut. The hairs on the shoulder, just after the posterior base of the ears, are darker than those in the remainder parts. Individual hairs are short and almost equal in length. The tail is robust and macular. It projects conspicuously beyond the narrow and naked interfemoral membrance. The skull is small with an average SL of $20.23 \mathrm{~mm}$ (19.58$20.92 \mathrm{~mm} ; \mathrm{n}=5$; table 2). The rostrum and brancse are narrower forewards and flatted, respectively (fig. 2). The sagittal crest is well defined but less developed. The mandible is strong but its coronoid process is less developed and lower than respective canine. The upper and lower canines are sharp and pointed (fig. 2). There are only one pair of upper incisors, which are remarkbly robust.

Table 2. Craniodental measurements (in $\mathrm{mm}$ ) of Chaerephon plicatus from Vietnam

\begin{tabular}{ccccc}
\hline Parameter & mean & Min-max & SD & $\mathrm{n}$ \\
\hline SL & 20.23 & $19.58-20.92$ & 0.55 & 5 \\
CCL & 17.36 & $17.19-17.64$ & 0.21 & 4 \\
IOW & 4.32 & $3.95-4.55$ & 0.16 & 15 \\
ZW & 11.81 & $11.46-12.27$ & 0.29 & 13 \\
BW & 11.17 & $10.45-11.70$ & 0.46 & 9 \\
C1-C1 & 5.04 & $4.92-5.26$ & 0.14 & 5 \\
M3-M3 & 8.61 & $8.03-9.31$ & 0.37 & 11 \\
C1-M3 & 7.56 & $6.91-8.58$ & 0.59 & 8 \\
ml & 13.48 & $13.26-13.64$ & 0.17 & 4 \\
c1-m3 & 7.98 & $7.91-8.10$ & 0.08 & 4 \\
\hline
\end{tabular}

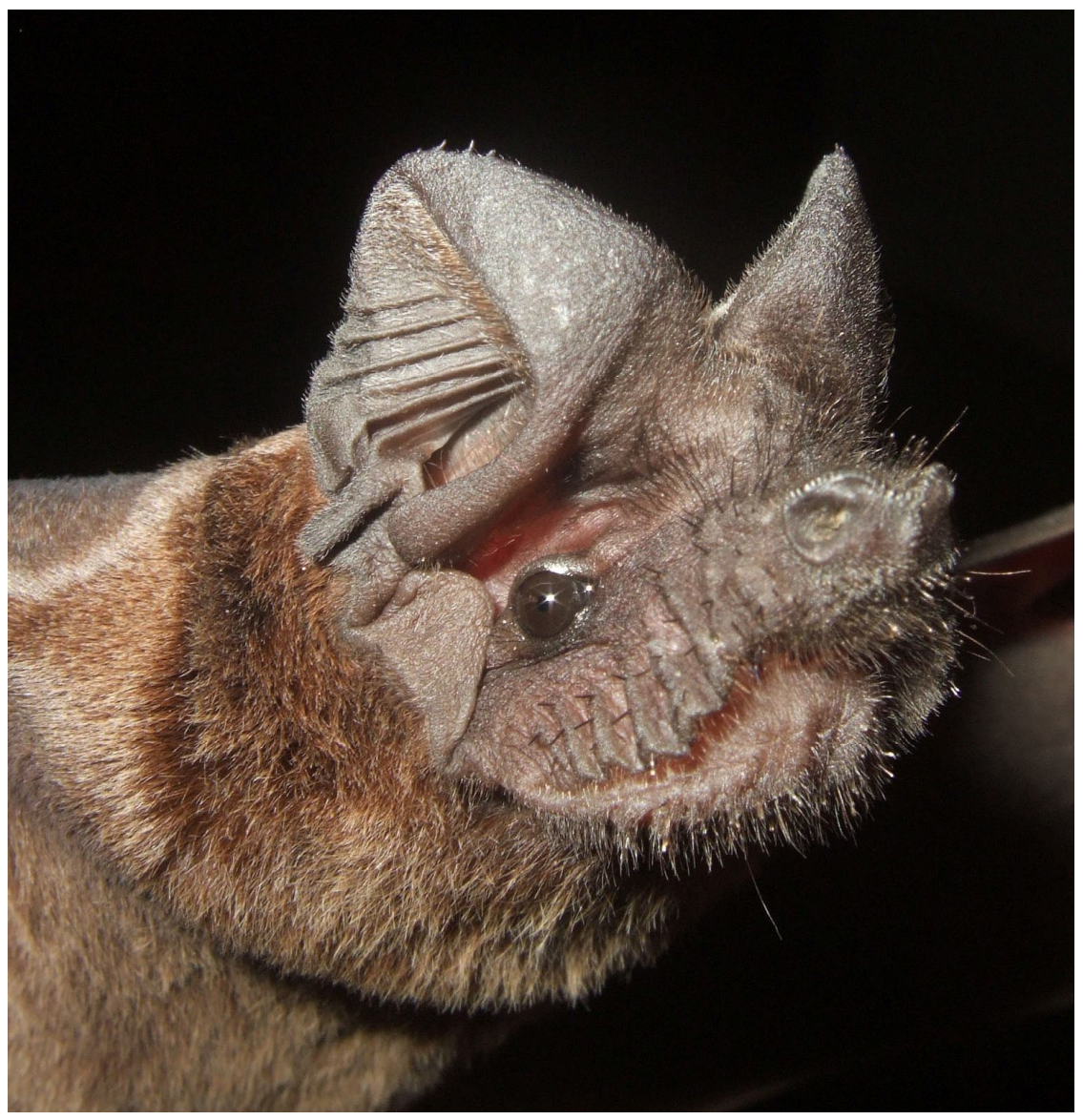

Figure 1. Face and ear of Chaerephon plicatus from Vietnam 


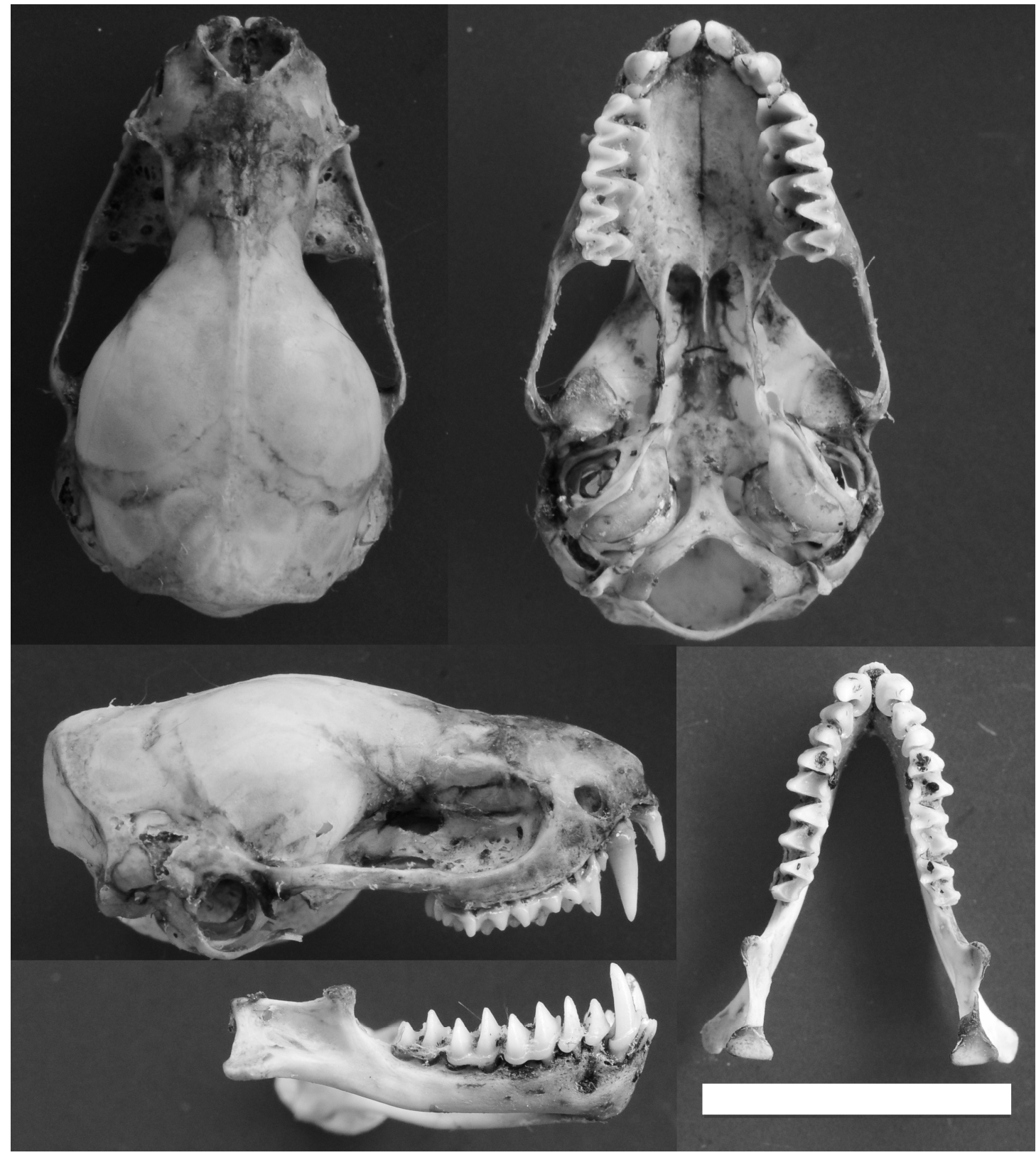

Figure 2. Ventral, dorsal, and lateral (from top-right anticlockwise) views of the skull and mandible of Chaerephon plicatus from Vietnam. Scale $=10 \mathrm{~mm}$.

\section{Distribution and ecology}

In Vietnam, Chaerephon plicatus is recorded from both northern and southern regions (fig. 3). All known roosting sites of the species are nested within the areas with limestone karst or rocks. Its colony at each site ranges between thounsands and millions of individuals. The northern colony, which contains over 3,000,000 individuals, seasonally inhabits a huge cave situated on a karst mountain beside a large rice field of Lang Son province. Other bat species recorded from the same cave are Cynopterus horsfieldii, Rousettus 
leschenaulti, Myotis chinensis and Taphozous melanopogon. The southern conlony inhabits permanently crevices in large piles of rocks and boulders of Dong Nai province. Based on information from interviews and a daytime observation at the sites, its size ranges from 600 to 800 individuals.

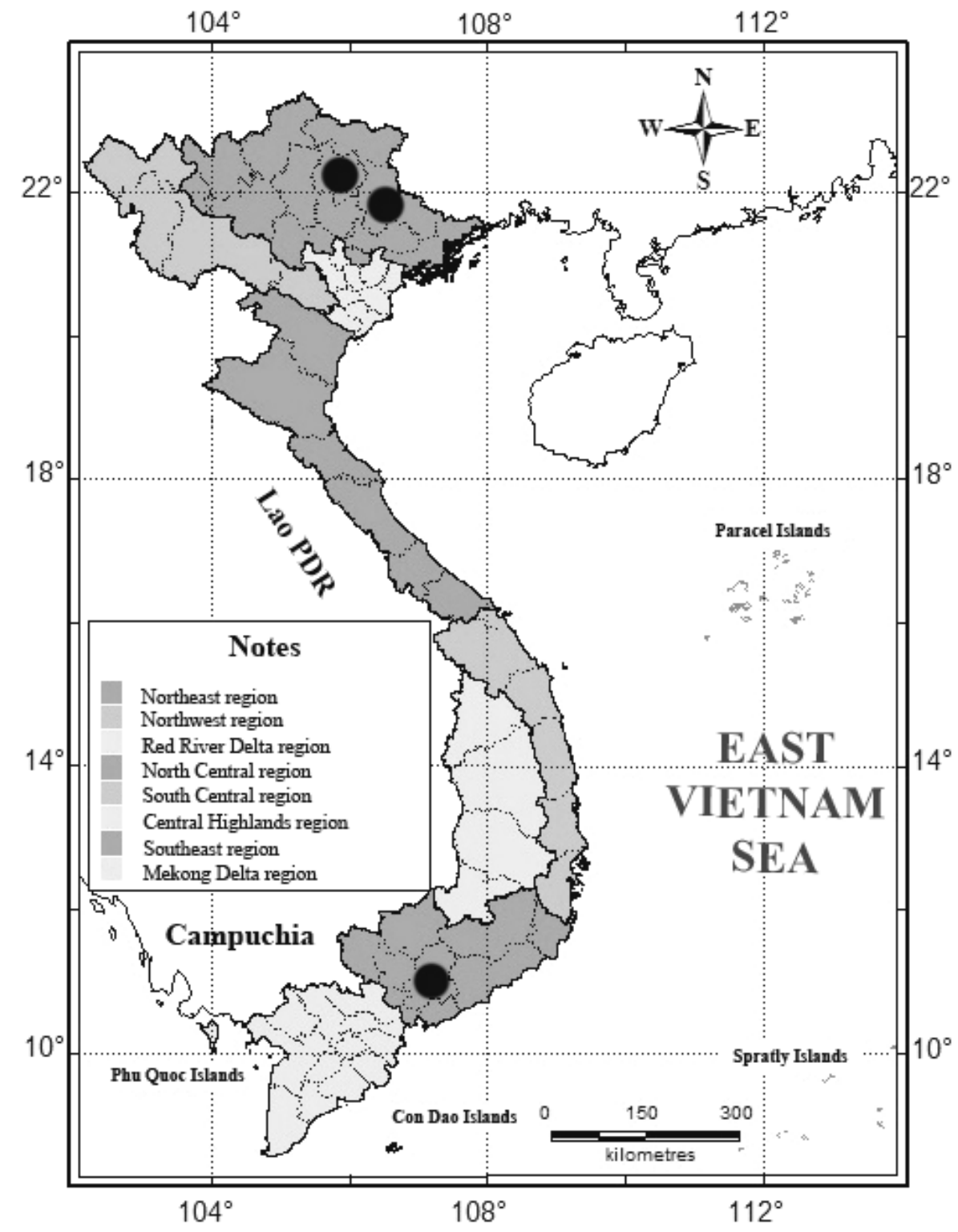

Figure 3. Currently known roosting sites of Chaerephon plicatus from Vietnam [ground map was adapted from Dang Ngoc Can et al. 2008]

\section{DISCUSSION}

Prior to the present study, Chaerephon plicatus was only known from several localities in northern Vietnam ranging from urban
(Hanoi) to karst habitats with primary forests (Ba Be and Xuan Son National Parks) and offshore island [2, 12, 17]. Chaerephon plicatus was classified as Tadarida (Chaerephon) 
plicata $[1,6]$. However, Chaerephon appears as a distinct genus and the species should be commonly treated as Chaerephon plicatus (Simmons 2005) [15]. In a number of publications, the scientific name of the species was spelled as either Tadarida plicata [11] or Chaerephon plicata [2, 8, 12]. Topal (1974) [17] recorded a single pregnant female without measurement. This record was followed by Dang Huy Huynh et al. (1994) [8] and Hendrichsen et al. (2001) [11]. Borissenko and Kruskop (2003) [2] mentioned a single (unsexed) specimen, which was cited in Kruskop (2013) [12], from the "Gulf of Tonkin", northeastern Vietnam. Detailed assessments of the taxonomic status of Chaerephon plicatus and an unidentified freetailed bat species from the country are in preparation for a forthcoming publication ( $\mathrm{Vu}$ Dinh Thong, in literature).

With a confirmation of the roosting site in Dong Nai province, results from the present study remarkably extend the potential distribution range of the species within the country. Annually, the northern colony only appears within two periods (March-June and Agust-October). Prior to August 2012, the northern colony was critically hunted by local people. With support from the Bat Conservation International, a series of solutions (awareness raising campaign, a lawful regulation with agreements signed between the author of this paper and local authorities, etc.) was implemented for urgent conservation of the greatest bat cave in Vietnam. Additionally, a guard station was also built in front of the cave for a local family staying to protect and monitor the colony. Without doubt, a long-term programme is clearly required for the maintainance of the guard station, extensive research and sustainable conservation of the colony in northern Vietnam.

\section{CONCLUSION}

Chaerephon plicatus is the only free-tailed bat species with confirmed taxonomy and distribution in Vietnam. Its taxonomic status and roosting sites of the species from the country are confirmed. The species is recorded in various habitats ranging from urban to karst forest areas. Its colony size ranges from six hundreds to over three million individuals. A long-term action plan is needed for both research and sustainable conservation of Chaerephon plicatus in Vietnam in coming time.

Acknowledgements: This research is funded by the Vietnam National Foundation for Science and Technology Development (NAFOSTED) under grant number 106.11-2012.02; the Bat Conservation International (BCI), USA. The author is very grateful to Dr. Dave Waldien (Senior Director, Global Conservation) of BCI; Prof. Hans-Ulrich Schnitzler, Dr. Annette Denzinger, Dr. Christian Dietz of the University of Tuebingen, Germany; Dr Paul J.J. Bates of the Harrison Institute, England; Prof. Paul Racey of the University of Exeter, England; Marianne Carter (Director of Conservation Capacity, Fauna \& Flora International) and the Management Team of the Conservation Leadership Programme (Robyn Dalzen, Stuart Paterson, Kiragu Mwangi, Julie Lewis, Christina Imrich, Iain Dickson); Dr. Neil Furey of the Fauna and Flora International (Cambodia); and to our colleagues at the Institute of Ecology and Biological Resources, Institute of Tropical Biology, VAST, and other institutions for their help and support.

\section{REFERENCES}

1. Bates P. J. J., Harrison D. L., 1997. Bats of the Indian Subcontinent. Harrison Zoological Museum, Sevenoaks, Kent, United Kingdom, 297 pp.

2. Borissenko A. V., Kruskop S. V., 2003. Bats of Vietnam and Adjacent Territories: an identification manual. Joint RussianVietnamese Science and Technological Tropical Centre, Moscow and Hanoi, Russia and Vietnam, $212 \mathrm{pp}$.

3. Brunet-Rossinni A. K., Wilkinson G. S., 2009. Methods for age estimation and the study of senescence in bats. In: Kunz T.H., Parsons S. (eds.) Ecological and Behavioral Methods for the Study of Bats, 2nd edition, 
Johns Hopkins University Press, Baltimore, pp. 315-325.

4. Buchannan F., 1782. Description of the Vespertilio plicatus. Transactions of the Linnean Society of London, Volume 5: 261263.

5. Cao Van Sung, 1976. New data on the morphology and biology of some rare mammals from north Vietnam. Zoologicheskii zhurnal, 55(12): 1880-1885 [in Russian].

6. Corbet G. B., Hill J. E., 1992. The Mammals of the Indomalayan Region. Oxford University Press, Oxford, England, $496 \mathrm{pp}$.

7. Csorba G., Ujhelyi P., Thomas N., 2003. Horseshoe Bats of the World (Chiroptera: Rhinolophidae). Alana Books, England, 160 pp.

8. Dang Huy Huynh (ed.), Dao Van Tien, Cao Van Sung, Pham Trong Anh, Hoang Minh Khien, 1994. Checklist of mammals in Vietnam. Publishing House "Science and Technics", Hanoi, 168 pp [in Vietnamese].

9. Francis C. M., 2008. A guide to the Mammals of Southeast Asia. Princeton University Press, Princeton, USA, 392 pp.

10. Freeman P. W., 1981. A multivariate study of the family Molossidae (Mammalia: Chiroptera): morphology, ecology, evolution. Fieldiana, No. 7, 92pp.

11. Hendrichsen D. K., Bates P. J. J., Hayes B. D., Walson J. L., 2001. Recent records of bats (Mammalia: Chiroptera) from Vietnam with six species new to the country. Myotis, 39:35-199.

12. Kruskop S. V., 2013. Bats of Vietnam: Checklist and an identification manual. Moscow, Russia, 299 pp.

13. Racey P. A., 2009. Reproductive assessment in bats. In: Kunz T.H., Parsons S. (eds.) Ecological and Behavioral Methods for the Study of Bats, 2nd edition, Johns Hopkins University Press, Baltimore, pp. 249-264.

14. Sikes R. S., Gannon W. L., and the Animal
Care and Use Committee of the American Society of Mammalogists, 2011. Guidelines of the American Society of Mammalogists for the use of wild mammals in research. Journal of Mammalogy 92:235-253.

15. Simmons N. B., 2005. Order Chiroptera. In: Wilson DE and Reeder DM (eds.) Mammal species of the world: A taxonomic and geographic reference. The Johns Hopkins University Press, Baltimore, 3rd edition, pp. 312-529.

16. Sokolov V. M., Kunznetzov G. V., Dang Huy Huynh, Cao Van Sung, Pham Trong Anh, 1986. [Taxonomic checklist of the mammal fauna of Vietnam] (pp. 5-14). In: Sokolov, V.E. (ed.) [Fauna and ecology of mammals and birds of Vietnam]. Moscow [in Russian].

17. Topal G., 1974. Field observation on Oriental bats: sex ratio and reproduction. Vertebr. Hung. XV: 83-94.

18. Vu Dinh Thong, 2011. Systematics and echolocation of rhinolophoid bats (Mammalia: Chiroptera) in Vietnam. PhD Thesis, University of Tuebingen, Tuebingen, Germany, $258 \mathrm{pp}$.

19. Vu Dinh Thong, Dietz C., Denzinger A., Bates P. J. J., Puechmaille S. J., Callou C., Schnitzler H.-U., 2012a. Resolving a mammal mystery: the identity of Paracoelops megalotis (Chiroptera: Hipposideridae). Zootaxa, 3505, 75-85.

20. Vu Dinh Thong, Puechmaille S. J., Denzinger A., Bates P. J. J., Dietz C., Csorba G., Soisook P., Teeling E. C., Matsumura S., Furey N., Schnitzler H. U., 2012b. Systematics of the Hipposideros turpis complex and a description of a new subspecies from Vietnam. Mammal Rev., 42: 166-192.

21. Vu Dinh Thong, Puechmaille S. J., Denzinger A., Dietz C., Csorba G., Bates P. J. J., Teeling E. C., Schnitzler H. U., 2012c. A new species of Hipposideros (Chiroptera: Hipposideridae) from Vietnam. Journal of Mammalogy, 93: 1-11. 


\title{
ĐÁNH GIÁ VỀ PHÂN LOẠI HỌC VÀ PHẠM VI PHÂN BỐ CỦA LOÀI DƠI THÒ ĐUÔI BÉ Chaerephon plicatus (Chiroptera: Molossidae) Ở VIẸT NAM
}

\author{
Vũ Đình Thống
}

Viện Sinh thái và Tài nguyên sinh vật, Viện Hàn lâm KH\&CN Việt Nam

\section{SUMMARY}

Cho tới nay, Dơi thò đuôi bé (Chaerephon plicatus) là loài duy nhất thuộc họ Molossidae hiện biết ở Việt Nam. Loài dơi này được ghi nhận ở khắp châu Á nhưng hiếm có ghi nhận ở Việt Nam. Những ghi nhận trước đây chỉ căn cứ trên một cá thể đơn lẻ với rất ít dẫn liệu về hình thái. Đặc biệt, chưa có tài liệu nào đề cập đến số lượng trong đàn hoặc nơi ở của loài dơi này ở Việt Nam. Từ năm 2001 đến 2014 , nhiều đợt điều tra thực địa về dơi đã được thực hiện trên phạm vi cả nước, tập trung vào tìm kiếm những loài dơi thò đuôi. Kết quả thu được qua thời gian điều tra cho thấy, dơi thò đuôi bé có phạm vi phân bố rộng nhưng nơi ở hiện biết cách nhau rất xa. Số lượng trong đàn của loài dơi này cũng thay đổi theo mùa và theo vị trí địa lý, từ vài trăm đến hơn ba triệu cá thể. Loài dơi này cư trú theo mùa ở miền Bắc nhưng định cư quanh năm ở miền Nam. Bài báo này cung cấp những đánh giá về phân loại học và phạm vi phân bố với những thông tin cơ bản về: đặc điểm hình thái, kích cỡ đàn, sinh cảnh nơi đậu và phạm vi phân bố của loài Dơi thò đuôi nhỏ ở Việt Nam.

Từ khóa: Dơi thò đuôi, mammalia, sinh cảnh, tập tính, thay đổi theo mùa.

Ngày nhận bài: 11-9-2014 